\title{
Comparing the Surgical Outcomes of Modified Quad and Triangle Tilt Surgeries to Other Procedures Performed in Obstetric Brachial Plexus Injury
}

\author{
Rahul K. Nath, Juan-Carlos Pretto, Chandra Somasundaram \\ Texas Nerve and Paralysis Institute, Houston, USA \\ Email: ${ }^{*}$ drnath@drnathmedical.com, chandra@drnathmedical.com
}

Received June 20, 2013; revised July 21, 2013; accepted July 29, 2013

Copyright (C) 2013 Rahul K. Nath et al. This is an open access article distributed under the Creative Commons Attribution License, which permits unrestricted use, distribution, and reproduction in any medium, provided the original work is properly cited.

\begin{abstract}
Purpose: To compare results from our surgical treatment experiences in children with obstetric brachial plexus injuries (OBPI), to those who have had other surgical treatments. Methods: We conducted a retrospective study in our medical records consisting of two groups of OBPI patients. Group 1: 26 OBPI children (16 girls and 10 boys), age range between 2.0 and 12.0 (mean age 6.9), who have undergone surgical treatments at other institutions between 2005 and 2010. Group 2: 45 OBPI children (20 boys and 25 girls), age between 0.7 and 12.9 (mean age 3.7), who have had modified Quad and triangle tilt surgical treatment between 2005 and 2010 at our institution. In both groups Mean modified Mallet scores and radiological scores were measured and compared. All measurements were made at least one year post surgery in both groups. Results: Post-operative mean modified Mallet score was $11.8 \pm 2.4$ in group 1 patients, whereas post-mean modified Mallet score was $20 \pm 2.7(\mathrm{P}<0.0001)$ following modified Quad and triangle tilt surgeries in group 2 patients. Further, their radiological scores such as posterior subluxation, and glenoid version were $13.4 \pm$ 21.3 and $-30.2 \pm 19.1$ in group 1 , whereas $32.1 \pm 13.5(\mathrm{P}<0.0004)$, and $-16.3 \pm 11.5(\mathrm{P}<0.008)$ in group 2 patients, when compared to normal values of 50, and 0 respectively. Conclusion: Patients who have had mod Quad and triangle tilt for OBPI obtained significantly better functional outcomes in modified total Mallet score as well as in radiological scores, when compared to those OBPI children, who underwent other procedures such as posterior glenohumeral capsulorrhaphy, biceps tendon lengthening, humeral osteotomy, anterior capsule release, nerve transfer/graft, botox and muscle/tendon transfer and release.
\end{abstract}

Keywords: Obstetric Brachial Plexus Injury; Triangle Tilt Surgery; Modified Quad Surgery; Modified Mallet; Radiological Score

\section{Introduction}

Obstetric brachial plexus injuries (OBPI) occur during the delivery process, and the incidence has been reported to vary between 0.38 and 5.8 for every 1000 live births [1-4]. The most frequent pattern of nerve injury occurs in the upper C5-C6 roots (Erb's palsy). Many of these injuries are transient, and therefore several patients recover spontaneously within the first three months of life. However, a significant proportion of these children tend to retain persistent limb deficits, never recover full function and develop permanent injuries $[1,5,6]$.

Inadequate recovery of neurological function in these patients lead to long-term morbidity by causing muscle imbalances and weakness around the shoulder (the del-

\footnotetext{
"Corresponding author.
}

toid and external shoulder rotators) [7-10], and bony deformities (glenohumeral dysplasia and joint incongruity) $[5,11,12]$. Early surgical interventions have been shown to improve the limb functions in this group of patients $[13,14]$.

We and other investigators have demonstrated that soft tissue procedures such as muscles release and tendon transfers [15-22] including the modified Quad procedure first described by Narakas and modified by the senior author (RKN) lead to better shoulder abduction and flexion through releasing the existing contractures. However, this procedure does not realign the deformed glenohumeral joint (GHJ). The triangle tilt surgery, developed by the senior author and the surgeon (RKN) has been shown to effectively address these bony deformities, which greatly improves overall functions of the shoulder [23-33]. In 
addition, we have previously demonstrated that this surgical procedure improves shoulder function in OBPI patients with SHEAR deformity [30], and is a salvage procedure in failed humeral osteotomy patients [23,31-33].

\section{Patients and Methods}

A retrospective study was conducted on children diagnosed with OBPI who came to our clinic with a history of prior operative procedures in other hospitals to correct their deformities before presenting to our institute (group 1), and OBPI children who came to our institute without prior surgeries and undergone triangle tilt and mod Quad surgery to correct their deformities (group 2).

Group 1: 26 OBPI children (16 girls and 10 boys), age range between 2.0 and 12.0 (mean age 6.9), who have undergone surgical treatment at other institutions between 2005 and 2010.

Group 2: 45 OBPI children ( 20 boys and 25 girls), age between 0.7 and 12.9 (mean age 3.9), who have had modified Quad and triangle tilt surgical treatment between 2005 and 2010 at our institution.

The nerve involvement in group 1 was C5-6 $(\mathrm{n}=6)$, C5-7 $(\mathrm{n}=7)$, and total $(\mathrm{n}=13)$ : and in group 2 C5-6 $(\mathrm{n}=$ $16)$, C5-7 $(n=20)$ and total $(n=9)$. Prior surgical procedures that the patients in group 1 have undergone at other clinics are included posterior glenohumeral capsulorrhaphy $(\mathrm{N}=2)$, biceps tendon lengthening $(\mathrm{N}=1)$, humeral osteotomy $(\mathrm{N}=5)$, and anterior capsule release $(\mathrm{N}=3)$, nerve transfer/graft $(\mathrm{N}=13)$, botox (6) and muscle/tendon transfer and release $(\mathrm{N}=7)$. We compared statistically the results from other procedures performed in other institutes to the results from our procedures at least with a follow up of one year. In addition, their radiological scores such as posterior subluxation, and glenoid version were measured from CT scans and Magnetic resonance imaging in both groups and compared.

\subsection{Clinical Assessment}

Patients were evaluated with a physical exam, and through the modified Mallet clinical assessment with video recordings of patients performing the following movements pre- and post-operatively: external rotation, hands to mouth, hands to neck, hands to spine, and supination. For each functional Mallet parameter, patients were scored on a scale of $1-5$ with 5 as normal function and 1 denoting lack of any movement.

\subsection{Radiological Evaluation}

CT or MRI images were used to measure the posterior humeral head subluxation (PHHA), glenoid version [34], and SHEAR deformity [35], which evaluate the bony deformities of the patients' shoulder joint before and after triangle tilt surgery. Posterior subluxation of the hu- meral head, expressed as percentage of humeral head anterior to the glenoid (normal value $=50$ ), was calculated from the ratio of the distance between the scapular line to the anterior aspect of humeral head and the greatest diameter of the head multiplied by 100 . The scapular deformity, also referred to as SHEAR deformity, was measured from the 3D reconstructions of the $\mathrm{CT}$ images. The area of the scapula visible above the clavicle was measured and divided with the total area of the scapula for both affected and normal sides. The ratio of the affected side was subtracted from that of the normal side and multiplied with 100 to obtain SHEAR deformity (normal value $=0$ ).

\subsection{Operative Technique}

Group 2 patients have undergone the triangle tilt surgery. This was developed by the lead author, and this procedure has been shown to have successful outcomes in OBPI patients [23-33]. The operative technique includes clavicle osteotomy at the intersection of its middle and distal third, acromion osteotomy at its intersection with the scapular spine and osteotomy of the scapula followed by splinting of the limb in adduction [23-33]. Group 2 patients have also undergone the transfer of the latissimus dorsi and teres major muscles, release of contractures of subscapularis pectoralis major and minor and axillary nerve decompression and neurolysis (the modified Quad procedure) $[17,36]$. The surgeon and the lead author (RKN), who has over 17 years of experiences in this field with several thousand OBPI patients performed all surgical procedures.

\subsection{Statistical Analysis}

The Student's t test statistic was applied to compare the mean Mallet scores and bony parameters between the both groups using the "Analyse it" plugin (Leeds, UK) for Microsoft Excel 2003. A value of $P<0.05$ was considered to be statistically significant.

\section{Results and Discussion}

The 26 OBPI patients from group 1 in our present study have had one or multiple surgical treatments with other surgeons before visiting our clinic (Table 1). These patients have undergone at least one of the following traditional approaches that are aimed to treat OBPI such as nerve transfer, contracture release, axillary nerve decompression, and external derotational osteotomy of the humerus.

Conventional surgical approaches fail to address the scapular hypoplasia, elevation and rotation (SHEAR) deformity [35] associated with most OBPI cases. Therefore, these patients had poor functions (mean modified 
Table 1. Surgical outcome of other surgeons.

\begin{tabular}{|c|c|c|c|c|}
\hline Patient & Gender & Age & $\begin{array}{l}\text { Surgeries } \\
\text { at other clinic }\end{array}$ & $\begin{array}{c}\text { Modified } \\
\text { Total } \\
\text { Mallet }\end{array}$ \\
\hline 1 & $\mathrm{~F}$ & 2.5 & Humeral head reposition & 13 \\
\hline 2 & M & 6.5 & $\begin{array}{l}\text { Nerve graft, Shoulder } \\
\text { capsular release }\end{array}$ & 11 \\
\hline 3 & $\mathrm{~F}$ & 4.1 & Nerve transfer & 13 \\
\hline 4 & $\mathrm{~F}$ & 12 & Nerve graft & 11 \\
\hline 5 & $\mathrm{~F}$ & 2.0 & Nerve graft & 12 \\
\hline 6 & M & 12 & Nerve graft & 11 \\
\hline 7 & M & 10.5 & Nerve transfer & 5 \\
\hline 8 & $\mathrm{~F}$ & 7.1 & Nerve graft & 11 \\
\hline 9 & M & 5.5 & $\begin{array}{l}\text { Humeral osteotomy, } \\
\text { coracoacromion release }\end{array}$ & 14 \\
\hline 10 & $\mathrm{~F}$ & 10.5 & Humeral osteotomy & 8 \\
\hline 11 & $\mathrm{~F}$ & 9.0 & Humeral osteotomy & 14 \\
\hline 12 & M & 11.2 & Muscle transfer \& release & 10 \\
\hline 13 & $\mathrm{~F}$ & 5.0 & Nerve graft & 10 \\
\hline 14 & M & 3.5 & Botox & 12 \\
\hline 15 & M & 1.9 & wrist capsular release & 12 \\
\hline 16 & $\mathrm{~F}$ & 2.0 & Neurolysis & 11 \\
\hline 17 & $\mathrm{~F}$ & 12.3 & Nerve graft & 9 \\
\hline 18 & $\mathrm{~F}$ & 8.5 & Capsular release & 12 \\
\hline 19 & $\mathrm{~F}$ & 12.0 & Acromionclavicular release & 14 \\
\hline 20 & M & 4.3 & $\begin{array}{l}\text { Tendon transfer \& } \\
\text { Neurolysis }\end{array}$ & 13 \\
\hline 21 & $\mathrm{~F}$ & 4.5 & Brachial Plexus Exploration & 17 \\
\hline 22 & $\mathrm{~F}$ & 6.7 & Nerve transfer & 11 \\
\hline 23 & $\mathrm{~F}$ & 6.8 & Tendon transfer & 14 \\
\hline 24 & M & 7.9 & Muscle transfer \& release & 15 \\
\hline 25 & M & 2.0 & Brachial Plexus Exploration & 13 \\
\hline 26 & $\mathrm{~F}$ & 10.0 & $\begin{array}{l}\text { Muscle \& tendon } \\
\text { transfer \& release }\end{array}$ & 12 \\
\hline
\end{tabular}

Mean: 11.8; STD: 2.4 .

Mallet score was $11.8 \pm 2.4$ (Table 1, Figures 1 and 2), and anatomical structures (mean PHHA $13.4 \pm 21.3$, version $-30.2 \pm 19.1$, and SHEAR $15.5 \pm 15.1$; Table 2 , Figures 3 and 4). Normal values are PHHA 50, glenoid version 0 and SHEAR 0.

In group 2 all the patients had poor shoulder abduction and flexion due to $\mathrm{C} 5$ injury present in all patients prior to surgery. The mod Quad procedure addresses these deformities, yet it does not address the SHEAR, and does not realign the deformed glenohumeral joint (GHJ). Therefore, the triangle tilt surgery was performed on these patients. This procedure has been shown to effectively address these bony deformities, and improves overall functions of the shoulder [23-33]. The functional benefits of mod Quad [17], and triangle tilt surgeries have been extensively discussed in our previous publications [23-33]. After undergone these two surgical proce-
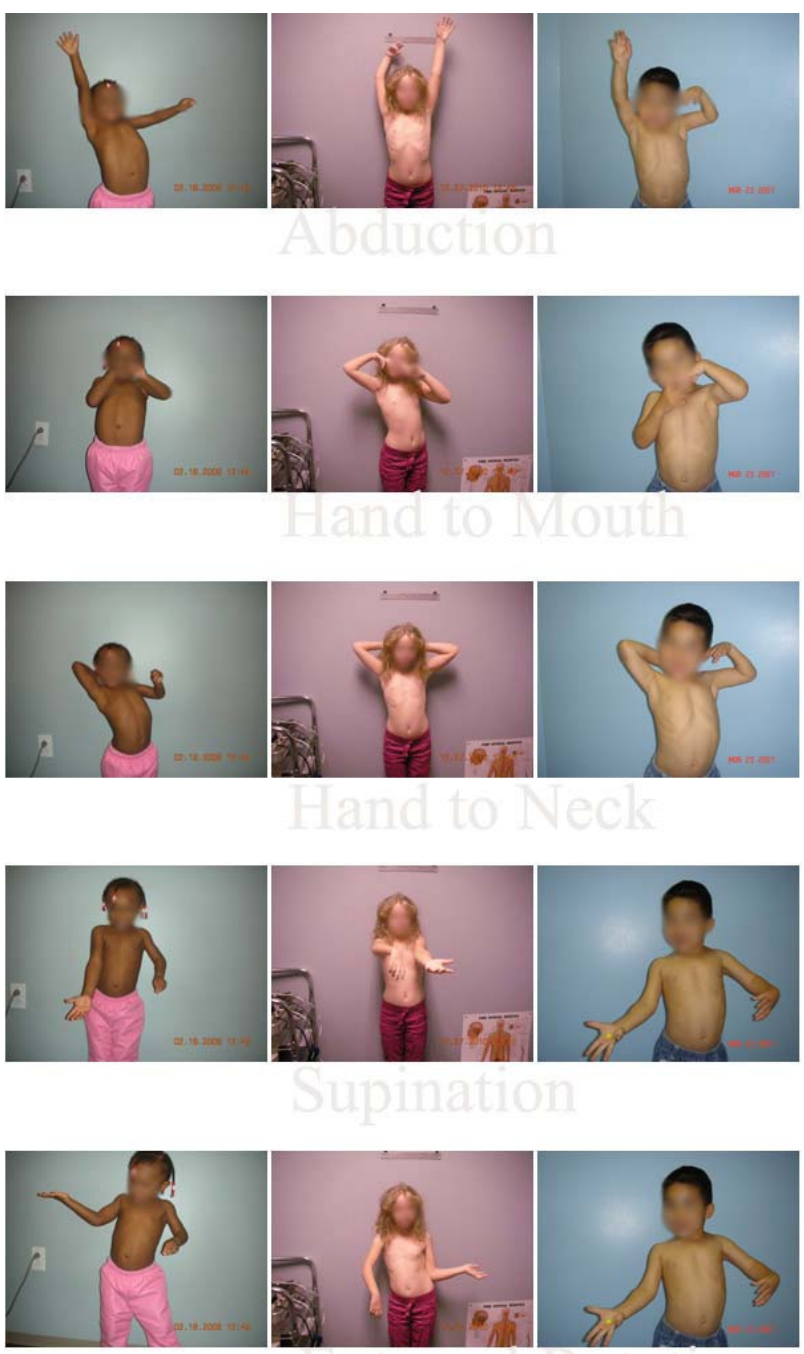

Figure 1. Modified Mallet functions performed by OBPI children, who have had surgeries at other clinic before presenting to us.

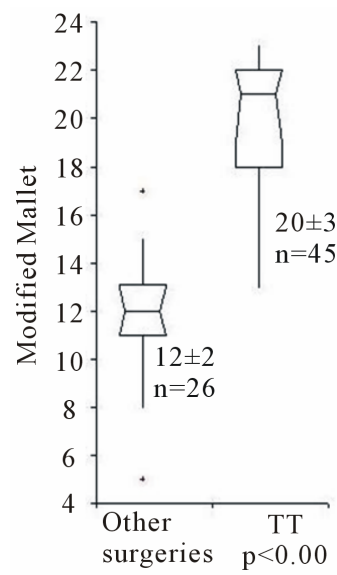

Figure 2. Statistical comparison of modified total Mallet of OBPI patients, who have had surgeries at other clinic with OBPI patients, who have had modified Quad and triangle tilt surgeries at our clinic. 


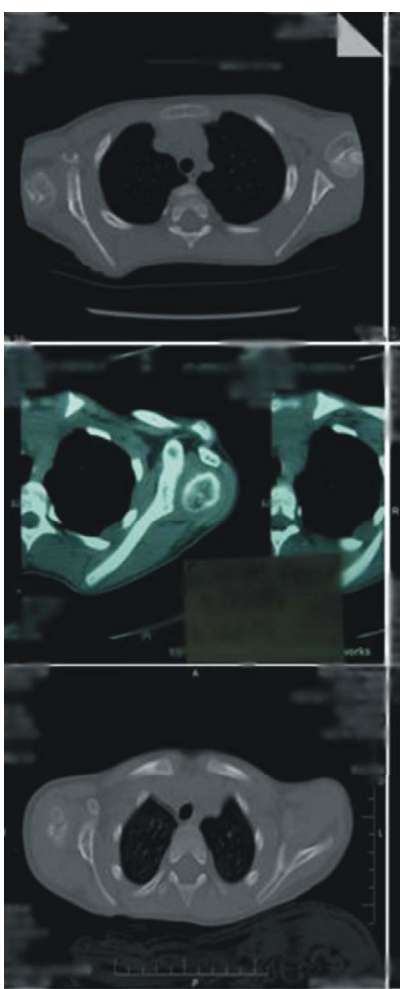

CT images- other surgeries

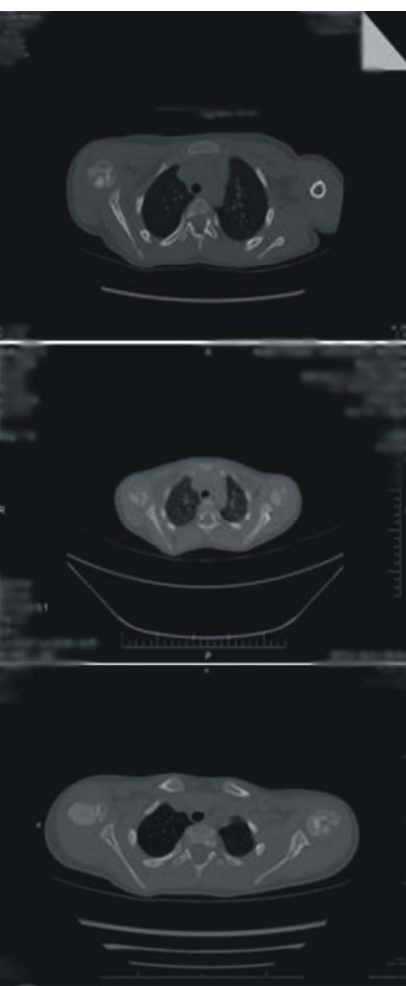

CT images- triangle tilt

Figure 3. Comparison of CT images of OBPI patients, who have had surgeries at other clinic with OBPI patients, who have had modified Quad and triangle tilt surgeries at our clinic.
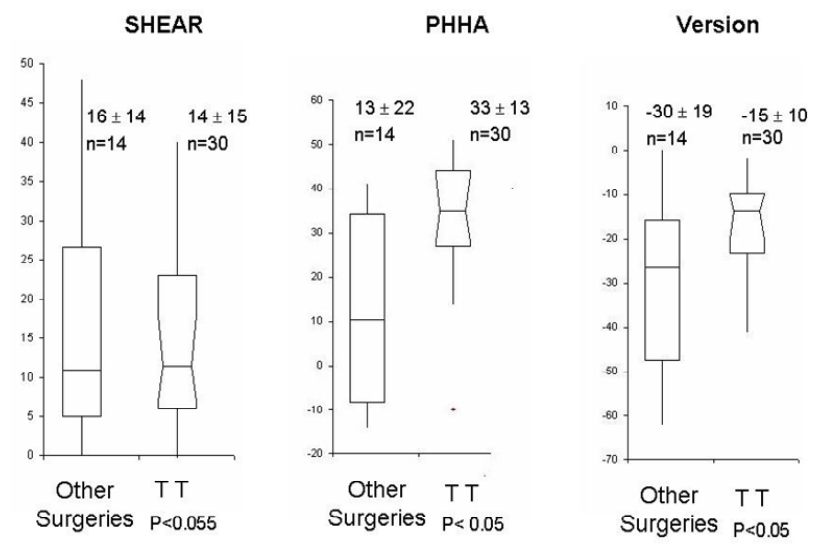

Figure 4. Statistical comparison of radiological scores of OBPI patients, who have had surgeries at other clinic with OBPI patients, who have had modified Quad and triangle tilt surgeries at our clinic.

dures with us, the group 2 patients have better results (mean Mallet score was $20 \pm 2.7$; Table 3, Figures 2 and $5)$, which is statistically significant $(\mathrm{P}<0.0001)$, when compared to the group 1 patients (mean Mallat score $11.8 \pm 2.4$; Table 1, Figures 1 and 2).

There was statistically significant improvement anatomically in group 2 patients, who have undergone train-

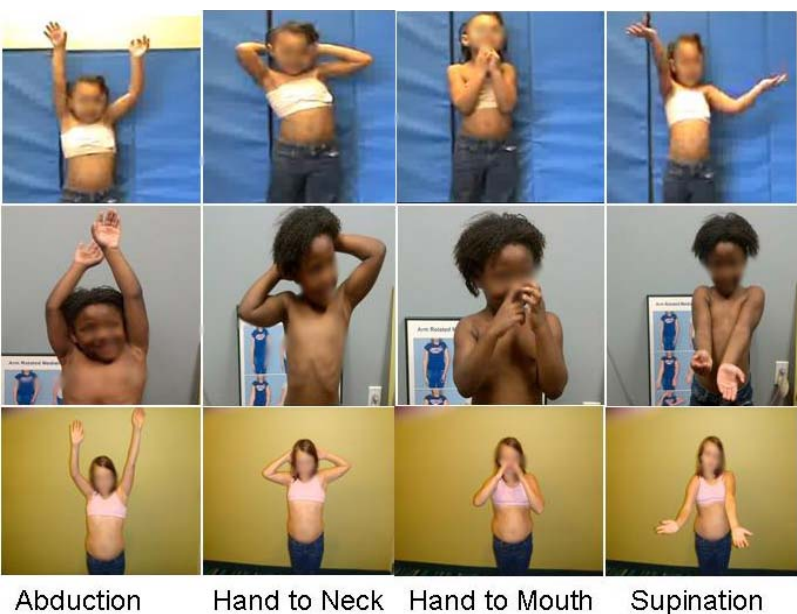

Figure 5. Modified Mallet functions performed by OBPI children, who have had modified Quad and triangle tilt surgeries at our clinic.

Table 2. Anatomical outcome (radiological scores) of other surgeries in OBPI.

\begin{tabular}{|c|c|c|c|c|c|c|}
\hline Patien & Gender & $\begin{array}{l}\text { Age } \\
\text { at TT }\end{array}$ & $\begin{array}{c}\text { Surgeries } \\
\text { at other } \\
\text { clinic }\end{array}$ & $\begin{array}{l}\text { PHНA } \\
\text { affected }\end{array}$ & $\begin{array}{l}\text { Version } \\
\text { affected }\end{array}$ & $\begin{array}{l}\text { SHEAR } \\
\text { affected }\end{array}$ \\
\hline 1 & $\mathrm{M}$ & 6.5 & NG & 8 & -47 & \\
\hline 2 & $\mathrm{~F}$ & 2.0 & $\mathrm{NG}$ & -7 & -62 & 8 \\
\hline 3 & $\mathrm{M}$ & 12 & NG & 34 & -20 & 0 \\
\hline 4 & M & 10.5 & NT & 33 & -16 & 15 \\
\hline 5 & $\mathrm{M}$ & 5.5 & $\mathrm{NG}$ & -12 & -51 & 30 \\
\hline 6 & $\mathrm{~F}$ & 10.5 & $\mathrm{HO}$ & 13 & -20 & 7 \\
\hline 7 & $\mathrm{M}$ & 9.0 & $\mathrm{HO}$ & 39 & 0 & 9 \\
\hline 8 & $\mathrm{~F}$ & 5.0 & NG & 38 & -10 & 0 \\
\hline 9 & $\mathrm{M}$ & 3.5 & BO & -8 & -38 & 11 \\
\hline 10 & $\mathrm{~F}$ & 2.0 & $\mathrm{NL}$ & -14 & -33 & 25 \\
\hline 11 & $\mathrm{~F}$ & 12 & NG & 0 & -45 & 32 \\
\hline 12 & $\mathrm{~F}$ & 12 & ACR & -11 & -53 & 48 \\
\hline 13 & $\mathrm{M}$ & 3.0 & NL & 33 & -18 & 1 \\
\hline & Mean & $\pm \mathrm{ST}$ & & $11.2 \pm 21.3$ & $31.8 \pm 19.1$ & $15.5 \pm 15.1$ \\
\hline
\end{tabular}

gle tilt (mean PHHA, and glenoid version were $32.1 \pm$ 13.5 and $-16.3 \pm 11.5$ respectively; Table 2 and Figures 3 and 4) than those who have undergone other procedures (mean PHHA and glenoid version were 13.4 \pm 21.3 and $-30.2 \pm 19.1$ respectively; Table 4, Figures 3 and 4). There was no significant difference in the outcome of SHEAR deformity between these two groups.

\section{Conclusion}

We have demonstrated in this report, the triangle tilt and modified Quad surgeries resulted in significantly better glenohumeral congruity and shoulder abduction respect- 
Table 3. Surgical outcome of triangle tilt.

\begin{tabular}{|c|c|c|c|}
\hline No & Gender & Age at TT & Post-TT Total Mallet \\
\hline 1 & $\mathrm{~F}$ & 1.3 & 23 \\
\hline 2 & $\mathrm{~F}$ & 2.8 & 21 \\
\hline 3 & M & 7.5 & 18 \\
\hline 4 & $\mathrm{~F}$ & 1.5 & 21 \\
\hline 5 & $\mathrm{~F}$ & 3.0 & 19 \\
\hline 6 & M & 12.9 & 16 \\
\hline 7 & $\mathrm{~F}$ & 2.5 & 23 \\
\hline 8 & $\mathrm{~F}$ & 1.3 & 23 \\
\hline 9 & M & 2.2 & 21 \\
\hline 10 & M & 7.3 & 19 \\
\hline 11 & $\mathrm{~F}$ & 0.8 & 23 \\
\hline 12 & $\mathrm{~F}$ & 9.3 & 17 \\
\hline 13 & M & 1.7 & 19 \\
\hline 14 & $\mathrm{~F}$ & 1.9 & 22 \\
\hline 15 & M & 3.0 & 23 \\
\hline 16 & $\mathrm{~F}$ & 1.3 & 22 \\
\hline 17 & $\mathrm{~F}$ & 3.6 & 20 \\
\hline 18 & M & 0.7 & 21 \\
\hline 19 & M & 11.6 & 16 \\
\hline 20 & $\mathrm{~F}$ & 1.5 & 15 \\
\hline 21 & M & 3.5 & 21 \\
\hline 22 & $\mathrm{~F}$ & 3.8 & 19 \\
\hline 23 & $\mathrm{~F}$ & 2.3 & 16 \\
\hline 24 & M & 1.6 & 23 \\
\hline 25 & F & 3.2 & 18 \\
\hline 26 & $\mathrm{M}$ & 1.3 & 23 \\
\hline 27 & $\mathrm{~F}$ & 0.9 & 16 \\
\hline 28 & $\mathrm{M}$ & 3.8 & 16 \\
\hline 29 & F & 2.5 & 23 \\
\hline 30 & F & 1.8 & 23 \\
\hline 31 & F & 7.5 & 21 \\
\hline 32 & F & 2.8 & 22 \\
\hline 33 & $\mathrm{~F}$ & 8.5 & 19 \\
\hline 34 & $\mathrm{M}$ & 1.1 & 18 \\
\hline 35 & F & 3.0 & 22 \\
\hline 36 & $\mathrm{~F}$ & 1.8 & 17 \\
\hline 37 & $\mathrm{M}$ & 2.0 & 22 \\
\hline 38 & $\mathrm{M}$ & 7.9 & 21 \\
\hline 39 & $\mathrm{~F}$ & 5.8 & 16 \\
\hline 40 & $\mathrm{M}$ & 2.8 & 23 \\
\hline 41 & $\mathrm{M}$ & 1.3 & 21 \\
\hline 42 & $\mathrm{M}$ & 7.3 & 13 \\
\hline 43 & $\mathrm{M}$ & 2.8 & 21 \\
\hline 44 & $\mathrm{M}$ & 1.7 & 22 \\
\hline 45 & $\mathrm{~F}$ & 7.9 & 22 \\
\hline
\end{tabular}

Mean \pm STD: $20 \pm 2$; P value: $<0.0001$.
Table 4. Anatomical outcome (radiological scores) of traingle tilt.

\begin{tabular}{|c|c|c|c|c|c|}
\hline No & Gender & $\begin{array}{l}\text { Age } \\
\text { at TT }\end{array}$ & $\begin{array}{l}\text { Post-op } \\
\text { PHHA- } \\
\text { affected }\end{array}$ & $\begin{array}{l}\text { Post-op } \\
\text { version } \\
\text { affected }\end{array}$ & $\begin{array}{l}\text { Post-op } \\
\text { SHEAR- } \\
\text { affected }\end{array}$ \\
\hline 1 & $\mathrm{~F}$ & 9.39 & 29 & -22 & 24 \\
\hline 2 & M & 1.72 & 31 & -12 & 29 \\
\hline 3 & $\mathrm{~F}$ & 1.90 & 38 & -2 & 6 \\
\hline 4 & $\mathrm{~F}$ & 5.90 & 43 & -6 & 9 \\
\hline 5 & F & 1.87 & 46 & -13 & 23 \\
\hline 6 & M & 7.37 & 15 & -45 & 37 \\
\hline 7 & M & 2.82 & 38 & -7 & 0 \\
\hline 8 & M & 8.02 & -10 & -41 & 18 \\
\hline 9 & M & 3.81 & 17 & -30 & 3 \\
\hline 10 & $\mathrm{~F}$ & 2.80 & 50 & -4 & 21 \\
\hline 11 & M & 2.21 & 38 & -7 & 0 \\
\hline 12 & M & 3.08 & 27 & -16 & 17 \\
\hline 13 & $\mathrm{~F}$ & 3.82 & 42 & -11 & 5 \\
\hline 14 & F & 2.35 & 46 & -12 & 6 \\
\hline 15 & F & 1.50 & 34 & -10 & -1 \\
\hline 16 & M & 1.33 & 50 & -5 & 23 \\
\hline 17 & M & 1.11 & 34 & -20 & 11 \\
\hline 18 & $\mathrm{~F}$ & 1.34 & 21 & -39 & 18 \\
\hline 19 & $\mathrm{~F}$ & 2.58 & 36 & -19 & 7 \\
\hline 20 & M & 1.65 & 27 & -19 & 12 \\
\hline 21 & $\mathrm{~F}$ & 0.78 & 26 & -10 & 9 \\
\hline 22 & $\mathrm{~F}$ & 2.53 & 14 & -27 & 40 \\
\hline 23 & $\mathrm{~F}$ & 1.36 & 44 & -14 & 8 \\
\hline 24 & $\mathrm{M}$ & 1.28 & 45 & -10 & 7 \\
\hline 25 & $\mathrm{~F}$ & 3.29 & 49 & -31 & 30 \\
\hline 26 & F & 3.68 & 33 & -26 & 12 \\
\hline 27 & M & 13.10 & 28 & -23 & 11 \\
\hline 28 & $\mathrm{~F}$ & 2.88 & 44 & -13 & 17 \\
\hline 29 & M & 1.66 & 51 & -3 & 3 \\
\hline 30 & M & 1.92 & 28 & -20 & 25 \\
\hline \multicolumn{2}{|c|}{ Mean } & \multicolumn{2}{|c|}{32.1} & -16.3 & 14.1 \\
\hline \multicolumn{2}{|c|}{ STD } & \multicolumn{2}{|c|}{13.5} & 11.5 & 10.9 \\
\hline \multicolumn{2}{|c|}{$P$ value } & \multicolumn{2}{|c|}{0.0004} & 0.008 & 0.76 \\
\hline
\end{tabular}

ively, and thus overall shoulder functions, when compared to the results obtained in those OBPI patients who have had other traditional surgeries at other institutes.

\section{REFERENCES}

[1] J. B. Adler and R. L. Patterson Jr., "Erb's Palsy. Long-Term Results of Treatment in Eighty-Eight Cases," The Journal of Bone and Joint Surgery (American Volume), Vol. 49, No. 6, 1967, pp. 1052-1064.

[2] A. F. Hoeksma, H. Wolf and S. L. Oei, "Obstetrical Brachial Plexus Injuries: Incidence, Natural Course and Shoulder Contracture," Clinical Rehabilitation, Vol. 14, No. 5, 2000, pp. 523-526. 


\section{doi:10.1191/0269215500cr341oa}

[3] S. L. Foad, C. T. Mehlman and J. Ying, "The Epidemiology of Neonatal Brachial Plexus Palsy in the United States," The Journal of Bone and Joint Surgery (American Volume), Vol. 90, No. 6, 2008, pp. 1258-1264. doi:10.2106/JBJS.G.00853

[4] E. D. Gurewitsch, E. Johnson, S. Hamzehzadeh and R. H. Allen, "Risk Factors for Brachial Plexus Injury with and without Shoulder Dystocia," American Journal of Obstetrics \& Gynecology, Vol. 194, No. 2, 2006, pp. 486-492. doi:10.2106/JBJS.G.00853

[5] R. Birch, G. Bonney and C. B. Wynn Parry, "Birth Lesions of the Brachial Plexus," In: R. Birch, G. Bonney and C. B. Wynn Parry, Eds., Surgical Disorders of the Peripheral Nerves, Churchill Livingstone, New York, 1998, pp. 209-233.

[6] A. Gilbert and J. L. Tassin, "Surgery Repair of the Brachial Plexus after Obstetric Paralysis," Chirurgie, Vol. 110, No. 1, 1984, pp. 70-75.

[7] R. Birch, "Late sequelae at the shoulder in obstetrical palsy in children," In: M. Randelli and J. Karlsson, Eds., Surgical Techniques in Orthopaedics and Traumatology, Elsevier, Paris, 2001, pp. 55-200-E-210.

[8] D. S. Kon, A. B. Darakjian, M. L. Pearl and A. E. Kosco, "Glenohumeral Deformity in Children with Internal Rotation Contractures Secondary to Brachial Plexus Birth Palsy: Intraoperative Arthrographic Classification," Radiology, Vol. 231, No. 3, 2004, pp. 791-795.

doi:10.1148/radiol.2313021057

[9] J. A. van der Sluijs, W. J. van Ouwerkerk, A. de Gast, P. I. Wuisman, F. Nollet and R. A. Manoliu, "Deformities of the Shoulder in Infants Younger than 12 Months with an Obstetric Lesion of the Brachial Plexus," The Journal of Bone \& Joint Surgery (British Volume), Vol. 83, No. 4, 2001, pp. 551-555. doi:10.1302/0301-620X.83B4.11205

[10] R. K. Nath, S. E. Mackinnon, J. N. Jensen and W. C. Parks, "Spatial Pattern of Type I Collagen Expression in Injured Peripheral Nerve," Journal of Neurosurgery, Vol. 86, No. 5, 1997, pp. 866-870. doi:10.3171/jns.1997.86.5.0866

[11] R. Birch, "Obstetric Brachial Plexus Palsy," Journal of Hand Surgery (British Volume), Vol. 27B, No. 1, 2002, pp. 3-8.

[12] P. M. Waters, "Obstetric Brachial Plexus Injuries: Evaluation and Management," Journal of the American Academy of Orthopaedic Surgeons, Vol. 5, No. 4, 1997, pp. 205-214.

[13] S. M. Shenaq, J. Y. Kim, A. H. Armenta, R. K. Nath, E. Cheng and A. Jedrysiak, "The Surgical Treatment of Obstetric Brachial Plexus Palsy," Plastic and Reconstructive Surgery, Vol. 113, No. 4, 2004, pp. 54E-67E. doi:10.1097/01.PRS.0000110215.61220.72

[14] R. K. Nath, C. Somasundaram and F. Mahmooduddin, "Comparing Functional Outcome of Triangle Tilt Surgery Performed before versus after Two Years of Age," The Open Orthopaedics Journal, Vol. 5, 2011, pp. 59-62. doi:10.1097/01.PRS.0000110215.61220.72

[15] M. M. Al-Qattan, "Latissimus Dorsi Transfer for External Rotation Weakness of the Shoulder in Obstetric Brachial
Plexus Palsy," Journal of Hand Surgery (British Volume), Vol. 28, No. 5, 2003, pp. 487-490. doi:10.1097/01.PRS.0000110215.61220.72

[16] T. A. El-Gammal, W. R. Saleh, A. El-Sayed, M. M. Kotb, H. M. Imam and N. A. Fathi, "Tendon Transfer Around the Shoulder in Obstetric Brachial Plexus Paralysis: Clinical and Computed Tomographic Study," Journal of Pediatric Orthopaedics, Vol. 26, No. 5, 2006, pp. 641-646. doi:10.1097/01.PRS.0000110215.61220.72

[17] R. K. Nath and M. Paizi, "Improvement in Abduction of the Shoulder after Reconstructive Soft-Tissue Procedures in Obstetric Brachial Plexus Palsy," The Journal of Bone \& Joint Surgery (British Volume), Vol. 89, No. 5, 2007, pp. 620-626. doi:10.1097/01.PRS.0000110215.61220.72

[18] A. Pagnotta, M. Haerle and A. Gilbert, "Long-Term Results on Abduction and External Rotation of the Shoulder after Latissimus Dorsi Transfer for Sequelae of Obstetric Palsy," Clinical Orthopaedics and Related Research, Vol. 426, 2004, pp. 199-205. doi:10.1097/01.PRS.0000110215.61220.72

[19] Y. Safoury, "Muscle Transfer for Shoulder Reconstruction in Obstetrical Brachial Plexus Lesions," Handchirurgie Mikrochirurgie Plastische Chirurgie, Vol. 37, No. 5, 2005, pp. 332-336. doi:10.1055/s-2005-872818

[20] J. A. van der Sluijs, W. J. van Ouwerkerk, A. de Gast, F. Nollet, H. Winters and P. I. Wuisman, "Treatment of Internal Rotation Contracture of the Shoulder in Obstetric Brachial Plexus Lesions by Subscapular Tendon Lengthening and Open Reduction: Early Results and Complications," Journal of Pediatric Orthopaedics B, Vol. 13, No. 3, 2004, pp. 218-224. doi:10.1055/s-2005-872818

[21] P. M. Waters and D. S. Bae, "The Early Effects of Tendon Transfers and Open Capsulorrhaphy on Glenohumeral Deformity in Brachial Plexus Birth Palsy," The Journal of Bone and Joint Surgery (American Volume), Vol. 90, No. 10, 2008, pp. 2171-2179. doi:10.2106/JBJS.G.01517

[22] P. M. Waters and D. S. Bae, "Effect of Tendon Transfers and Extra-Articular Soft-Tissue Balancing on Glenohumeral Development in Brachial Plexus Birth Palsy," The Journal of Bone and Joint Surgery (American Volume), Vol. 87, No. 2, 2005, pp. 320-325. doi:10.2106/JBJS.G.01517

[23] R. K. Nath, M. B. Avila and P. Karicherla, "Triangle Tilt Surgery as Salvage Procedure for Failed Shoulder Surgery in Obstetric Brachial Plexus Injury," Pediatric Surgery International, Epub Ahead of Print, 2010.

[24] R. K. Nath, A. Amrani, S. E. Melcher, M. J. Wentz and M. Paizi, "Surgical Normalization of the Shoulder Joint in Obstetric Brachial Plexus Injury," Annals of Plastic Surgery, Vol. 65, No. 4, 2010, pp. 411-417.

[25] R. K. Nath, A. Amrani, S. E. Melcher and M. G. Eichhorn, "Triangle Tilt Surgery in an Older Pediatric Patient with Obstetric Brachial Plexus Injury," Eplasty, Vol. 9, 2009, p. e26.

[26] R. K. Nath, A. Amrani, S. E. Melcher, M. J. Wentz and M. Paizi, "Surgical Normalization of the Shoulder Joint in Obstetric Brachial Plexus Injury," Annals of Plastic Surgery, Vol. 65, No. 4, pp. 411-417. 


\section{doi:10.1097/SAP.0b013e3181e1335b}

[27] R. K. Nath, M. B. Avila, P. Karicherla and C. Somasundaram, "Assessment of Triangle Tilt Surgery in Children with Obstetric Brachial Plexus Injury Using the Pediatric Outcomes Data Collection Instrument," Open Orthopaedics Journal, Vol. 5, No. 12, 2011, pp. 385-388.

[28] R. K. Nath, X. Liu, S. E. Melcher and J. Fan, "LongTerm Outcomes of Triangle Tilt Surgery for Obstetric Brachial Plexus Injury," Pediatric Surgery International, Vol. 26, No. 4, 2010, pp. 393-399. doi:10.1007/s00383-010-2550-4

[29] R. K. Nath and F. Mahmooduddin, "Triangle Tilt Surgery: Effect on Coracohumeral Distance and External Rotation of the Glenohumeral Joint," Eplasty, Vol. 10, No. 11, 2010, p. e67.

[30] R. K. Nath, S. E. Melcher, A. B. Lyons and M. Paizi, "Surgical Correction of the Medial Rotation Contracture in Obstetric Brachial Plexus Palsy," The Journal of Bone \& Joint Surgery (British Volume), Vol. 89, No. 12, 2007, pp. 1638-1644. doi:10.1302/0301-620X.89B12.18757

[31] R. K. Nath, S. E. Melcher and M. Paizi, "Surgical Correction of Unsuccessful Derotational Humeral Osteotomy in Obstetric Brachial Plexus Palsy: Evidence of the Significance of Scapular Deformity in the Pathophysiology of the Medial Rotation Contracture," Journal of Brachial
Plexus and Peripheral Nerve Injury, Vol. 1, No. 12, 2006 , p. 9. doi:10.1302/0301-620X.89B12.18757

[32] R. K. Nath, C. Somasundaram and F. Mahmooduddin, "Triangle Tilt and Steel Osteotomy: Similar Approaches to Common Problems," The Open Orthopaedics Journal, Vol. 5, No. 2011, pp. 124-133. doi:10.1302/0301-620X.89B12.18757

[33] R. K. Nath, C. Somasundaram, S. E. Melcher, M. Bala and M. J. Wentz, "Arm Rotated Medially with Supination -The Arms Variant: Description of Its Surgical Correction," BMC Musculoskeletal Disorders, Vol. 10, No. 3, 2009, p. 32. doi:10.1186/1471-2474-10-32

[34] R. J. Friedman, K. B. Hawthorne and B. M. Genez, "The Use of Computerized Tomography in the Measurement of Glenoid Version," The Journal of Bone and Joint Surgery (American Volume), Vol. 74, No. 7, 1992, pp. 1032-1037.

[35] R. K. Nath and M. Paizi, "Scapular Deformity in Obstetric Brachial Plexus Palsy: A New Finding," Surgical and Radiologic Anatomy, Vol. 29, No. 2, 2007, 133-140. doi:10.1007/s00276-006-0173-1

[36] R. K. Nath and C. Somasundaram, "Successful Outcome of Modified Quad Surgical Procedure in Preteen and Teen Patients with Brachial Plexus Birth Palsy," Eplasty, Vol. 12, No. 12, 2012, p. e54. 